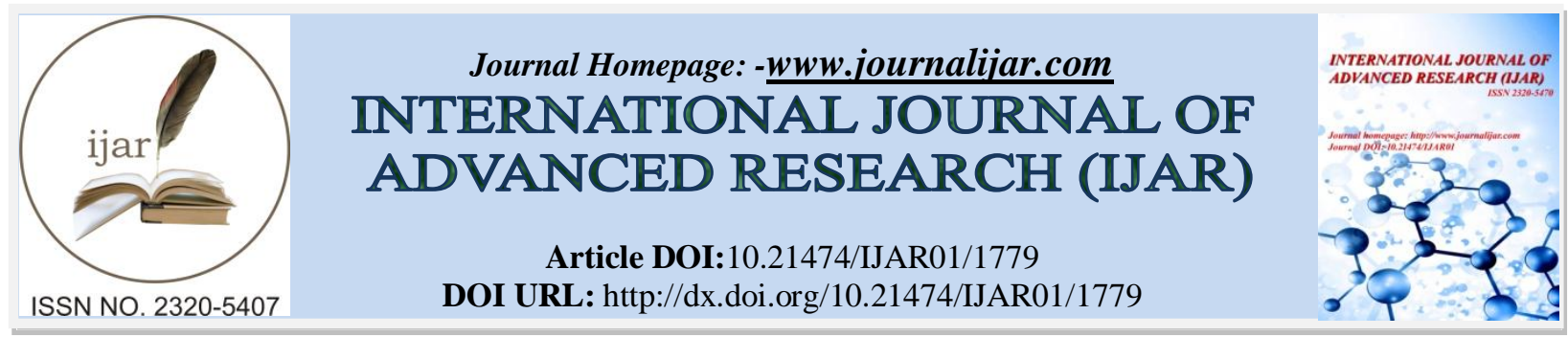

RESEARCH ARTICLE

THE DISPUTED HISTORICAL ARTEFACTS.

Joseph Kay.

Manuscript Info

Manuscript History

Received: 13 August 2016

Final Accepted: 12 September 2016

Published: October 2016

Key words:-
Abstract

The importance of discovered historical artefacts, their location and the on-going dispute over their ownership especially in the postcolonial world.

Copy Right, IJAR, 2016,. All rights reserved.

Whose Side Are You On?

The relevance of a given period in history is best revealed in the collection of artifacts of that time and place, perhaps more significantly than the chronicled word itself.Artifacts contribute tangible and visual quality to the narration of a time past. This realizationalso throws up serious anomalies in the present location and preservation of such artifacts. As political boundaries and conditions change, ownership issues become a bone of contention between nations. The colonial era as well as the two world wars saw the well-intentioned, systematic removal of ancient artifacts from their places of origin to what was perceived to be safer, well-guarded museums around the world. Often priceless items listed as national treasures of one country are found to have been acquired under dubious circumstances and preserved in a locale or museum that has no relation whatsoever with the history or culture of the land whose exhibitsthey aredisplaying. Famous disputes over ownership of ancient artefacts have often spilled into the media over the years whenever a questionable object of history winds up among auctioneers, private collectors or even national museums. From priceless thrones and jewels of flamboyant monarchs to the equally priceless pair of aMahatma Gandhi's humble leather sandals, glasses, watch or other personal effects. The demand for repatriation of their artifacts abroad has been getting more vociferous with the newer generation across the globe, even hoping to use it as a bargaining and a political leverage.

Much before France agreed to return more than one dozen Maori heads taken from New Zealand more than a century ago, there has been bitterness over loss of native items of reverence, worship and historical significance. Resentment over the disrespect of legacy by thearbitrary relocation of such relics by powers that were.

Below are some interesting ongoing disputes between nations over prized ancient artefacts:

\title{
The Elgin Marbles:-
}

Britain and Greece have had a long and bitter squabble over the Elgin Marbles, also known as the Parthenon Marbles, a collection of classical Greek sculptures that were originally part of the Parthenon and other buildings on the Acropolis of Athens. In the late 1700s, the 7th Earl of Elgin,Thomas Bruce with the connivance of the British ambassador to the Ottoman Empire, obtained permission to remove these sculptures from the Acropolis from the Ottoman regime under very controversial circumstances, criticized even at that time. Between 1801 and 1812, Elgin removed roughly half the surviving marblemonuments from the Parthenon to Britain where they ultimately ended up 
in the British Museum. On moral and artistic grounds, the Greeks want them back in their original locations at Athens. Britain has refused.

\section{The Kohinoor diamond:-}

The Koh-i-noor, a 105 carat diamond (in its most recent cut), which in Persian means "Mountain of Light", once the largest known diamond in the world, originated in the present state of Andhra Pradesh (India) along with its double, the Darya-i-noor (the "Sea of Light"). Through history it changed hands within India among various Hindu, Mughal, Afghan, Persian, Sikh and British rulers as a spoil of war many times. Finally, the East India Company seized it under debatable circumstances to become part of the British Crown Jewels when Queen Victoria was proclaimed Empress of India two decades following the mutiny of 1857. Though the present Indian government has claimed it as an illegal acquisition by Britain, in a July 2010 interview, David Cameron stated that returning the gem would set a precedent that could lead to suddenly finding the British Museum empty! The gem today remains the property of the British Crown and is housed in the Tower of London as a popular public and tourist attraction.

\section{Pemulwuy's head:-}

Of the more gruesome artifacts in contention is that of Pemulwuy's head. A charismatic Aboriginal leaderwho waged a war against the British settlers in Australia in the early 1800s, Pemulwuy was shot and beheaded mercilessly when the British quelled the uprising, following which his head was sent to Britain "to study" at the Royal College of Surgeons in London. The head, among others, were treated as a novelty, an object of curiosity, as nobody had ever seen what Australian Aborigines looked like. Many natives of Australia believe the chief's head is still somewhere in England along with the remains of other 3000 Aborigines, preserved by the British for scientific study. Various versions abound as to how the skulls may have been "lost," which include the Second World War bombing of the college in 1941 and another story that Pemulwuy's skull was bottled and returned to Australia sometime in 1950 and somehow lost.Sydney's Aborigines have demanded the head back to give it an honorable burial and even requested Prince William to help investigate the whereabouts of the head.

\section{Machu Picchu artefacts:-}

A long and bitter dispute which involved Peru's filing a lawsuit in the US against Yale Universityhas led to an agreement to return thousands of artefacts including 4,000 objects, items of pottery, textiles and bones to Peru, removednearly a century ago from the Inca citadel of Machu Picchu by American explorer and scholar Hiram Bingham III between 1911 and 1915 and donated to Yale. They include mummies, skulls, bones and other human remains apart from bronze, gold, metal artifacts, pottery, ceramics, utensils and ancient art-work. Finally, an exhibit for the recovered artifacts was opened to the public in April 2011 at the Government Palace in Lima, Peru.

\section{The Axum Obelisk:-}

Looted by Italian troops in 1937, the 1,700-year-old Axum Obelisk - believedto be a creation of one of the great kingdoms of the ancient world was returned to Ethiopia in 2005, after 70 years in Italy. It is a 24-metre-tall (79-foot) piece ofcarved and engraved granite stele. Returning the 160-ton obelisk back to Ethiopia cost the Italian government $\$ 7.7$ million in dismantling and freight. To prevent the obelisk from freezing in flight, heaters were installed on the planes and the monument was strapped with steel scaffolding to keep it from shaking or shifting during the six-hour flight to Ethiopia. The monument was eventually resurrected in its original home and unveiled on 4th September 2008.

\section{Ancient Persian Clay Tablets:-}

American archaeologists discovered the 2500-year-old ancient tablets in Persepolis, the ancient capital of the Persian Empire. They brought them to the University of Chicago in 1937 for study and historical research. About 37,000 of the artifacts were studied and returned to Iran's Cultural Heritage and Tourism Organization while some 5,000 still remain at the University of Chicago's Oriental Institute Museum. Meanwhile, the surviving victims of a 1997 bomb attack in downtown Jerusalemby the militant group Hamas, are demanding that the University of Chicago auction off the remaining ancient clay tablets, as the Iranian government, responsible for training Hamas, and who carried out the bombing at the Ben Yehuda mall, needed to compensate the injured and fatally wounded 100 civilians.In 2003, a Washington court ruling awarded the survivors of the bombing more than $\$ 250$ million in damages to be paid for by the Iranian government. Seeing the long-drawn exercises involved in securing the money, these survivors suggest that the remaining clay tablets be sold by the University of Chicago to pay for their awarded damages. However, the matter is still being litigated.

\section{Temple of PreahVihear:-}


When the French withdrew in the 1950s, Cambodia and Thailand became embroiled in relentless skirmish over the ownership of an ancient stone-walled temple called PreahVihear by the Cambodians and KhaoPhraViharn in Thailand. It would appear to be a land dispute, to be determined by locating exactly where the border between the two nations lay, but the main object of contention is the temple

In a 1962 decision, the International Court of Justice gave Cambodia sovereignty of the surrounding land. By nine votes to three, the court found that the Temple of PreahVihear was situated in territory under the sovereignty of Cambodia and, in consequence, Thailand was under obligation to withdraw any military or police forces, or other guards or keepers, stationed by her at the Temple, or in its vicinity on Cambodian territory. By seven votes to five, the Court found that Thailand was under an obligation to restore to Cambodia any sculptures, stelae, fragments of monuments, sandstone model and ancient pottery which might, since the date of the occupation of the Temple by Thailand in 1954, have been removed from the Temple or the Temple area by the Thai authorities.In 2008 the United Nations Educational, Scientific and Cultural Organization announced the temple a World Heritage with ownership to Cambodia following which the mini-war resumed. The United Nations ordered a ceasefire between the two nations in February 2011 despite which about 30 people died and some 85,000 people were evacuated from the area of conflict.

\section{The MohenjoDaro- Harappa Artefacts:-}

Discovered in the 1920s, Mohenjo-daro in the Sindhi language means "Mound of the Dead Men", an archeological site in the province of Sindh, Pakistan. Built around 2500 BCE (recent evidence suggests even 4000 BCE), it was one of the largest and earliest ancient human urban settlements, today referred to as the Indus Valley Civilization or Harappan Civilization, contemporaneous or even preceding the civilizations of ancient Egypt, Mesopotamia, Minoa, and Norte Chico. The site was rediscovered by R. D. Banerji, an officer of the Archaeological Survey of India on a visit to the site in 1919-20. Following this the site has been studied, excavated and brought to the limelight byKashinath Narayan Dikshit in 1924-25, John Marshall in 1925-30, andD. K. Dikshitar and Ernest Mackay in the later years. Further excavations were carried out in 1945 by Ahmad Hasan Dani and Mortimer Wheeler. Among the many artefacts discovered at the site are a 6.9 inches soapstone bust of a bearded man christened "The Priest King", a naked bronze figurine of a girl labelled "The Dancing Girl, Seals of various kinds depicting bulls and a seated figure of a man in a meditative position referred to as the "Pashupati" seal, a seven-stranded bronze-alloy nugget necklace with a S-shaped clasp, copper and stone tools, balance-scales and weights, gold and jasper jewelry, and children's toys. Many important objects from Mohenjo-daro are conserved at the National Museum of India in Delhi and the National Museum of Pakistan in Karachi. In 1939, under British India, the Director-General of the Archaeological Survey of India, transferreda representative collection of artefacts excavated at the site to the British Museum. When the British left India dividing the erstwhile colony into India and Pakistan, a Partition Council divided many of the artefacts between the two countries, even cutting and separating beads from priceless necklaces to equally divide the treasure on a 50:50 basis. Following wars and strained relationship between both nations, India returned the Priest King to Pakistan. However, Pakistan is now claiming ownership of the Dancing Girl and demanding its return too. One item that went unscathed in the division of artefacts was the seven-stranded bronze nugget necklace which, in the turmoil and confusion of Partition, Mortimer Wheeler never declared to the Archaeological department and instead gifted it to his wife, who in turn gifted it to an Indian lady. Discovered in 1945 in the Granary area of the excavation site, the existence of the necklace came to light only a few decades later and its legal status / provenance allowed only the British government to really make a claim on it as neither India nor Pakistan ever possessed it. But Britain no longer showed any interest in the items of the sub-continent. Though international collectors and buyers have made offers for it, today the priceless necklace is part of a private collection at Bangalore, India.

\section{The Sphinx's Beard:-}

The Sphinx, the most famous symbol of ancient Egypt, a monument built in the fourth dynasty period depicting the image of Pharaoh Khafre suffered damage when the beard of the 4,600-year-old artifact accidentally fell off, and lay buried in the sand. In 1818, it was carted away and sold to the British Museum. It is today stored in a basement in the UK and all requests for its return by Egyptian authorities have been refused.

\section{The Rosetta Stone:-}

A black granodiorite stone bearing ancient inscriptions in Greek, demotic characters and hieroglyphicswith a decree issued at Memphis, Egypt, in 196 BC on behalf of King Ptolemy V, was discovered in Rosetta, Egypt in 1799 by a 
French officer during theNapoleonic expedition to Egypt.Known as the Rosetta Stone, the 2,200-year-old famous artifact is believed to hold the key to translating the hieroglyphics of Egypt, as it was the first ancient Egyptian bilingual text recovered in modern times, arousing academic interest among historians and archaeologists with its potential to decipher previously untranslated hieroglyphic language. The stone was transferred to the British Museum in London after the defeat and surrender of the French in 1801. It is still the subject of dispute between nations today with Egypt continuing to seek for the stone's return.

\section{The Bust of Nefertiti:-}

The 3,300-year-old bust is a true to life statue of the wife of pharaoh Akhenaten, whose name was erased from all Egyptian monuments shortly after his death in 1338 B.C. by priests who disapproved of his religious beliefs and practices.The beautiful bust, now in Berlin was allegedly stolen in 1913 by German archaeologists using illegal documents. The bust was discovered by German archaeologist Ludwig Borchardt in 1912 and taken to Germany in1913. Although Egypt has persistently requested the return of Nefertiti to Egypt since 1930, Germany has refused to return the ancient bust contending that the statue was too delicate to move or make the long trip to Egypt. The bust of Nefertiti is the central attraction of the Egyptian collection at the Neues Museum in Berlin, drawing more than 1 million viewers annually. The German reluctance is best voiced by the Prussian Cultural Heritage Foundation President Professor Hermann Parzinger, who said. " The foundation's position on the return of Nefertiti remains unchanged. She is and remains the ambassador of Egypt in Berlin."

\section{Old Fisherman from Aphrodisias:-}

The Old Fisherman from Aphrodisias is a 2000-year-old or older marble torso. The torso was found in 1904 and today is in the Pergamon Museum in Berlin, while the head was discovered only in 1989 and remains in Aphrodisias.The Aphrodisias Fisherman is modeled on a once-famous Hellenistic statue of the third or second century BC. Though the original is now lost, about twenty marble versions of it from the Roman period have survived. These versions reveal that the original sculpture emphasized the most miserable and harsh features of a toiling human figure. A scrawny, aging body that appears to have endured back-breaking toil, poverty-stricken and wearing a slave's crude loin cloth, a stark departure from the Adonis-like male sculpture tradition of those times. Turkey has been demanding the return of the torso which has been persistently refused by German authorities. The stance taken by Hermann Parzinger, president of the Foundation of Prussian Cultural Heritage is that "It was bought from an art market, it was absolutely legal and we can prove it. We see no reason at all which would justify returning it."

\section{The Ishtar Gate:-}

Excavated and acquired by German archaeologists before the First World War, from the region that is today Iraq, the Ishtar Gate was the eighth gate to the inner city of Babylon. The magnificent structure was built about 575 BCE by order of King Nebuchadnezzar II on the north side of the city, using glazed brick with alternating rows of basrelief dragons and bulls, symbolizing the gods Marduk and Adad respectively.The gate, being part of the Walls of Babylon, was considered one of the original Seven Wonders of the World. The Ishtar Gate and Processional Way was dismantled brick-by-brick andrebuilt at the Pergamon Museum in Berlin out of material excavated by Robert Koldewey a German archaeologist,and finished in the 1930s including the original King Nebuchadnezzar II

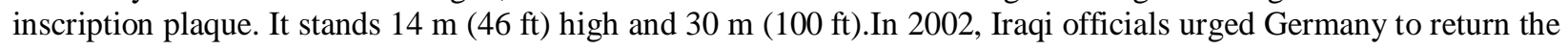
gate but Germany has adamantly refused, stating that there were no plans for its return.

\section{The Sion Treasure:-}

Turkey has been requesting the return of some forty items of ancient 6th century Byzantine liturgical silverware and other decorative objectssuch as plates, candlesticks, crosses and plaques known as the Sion Treasure found in an ancient burial mound in Kumulca, Turkey in the 1960s, among the many items it is seeking to recover from Dumbarton Oaks in Washington D.C., a research institute under Harvard University. The treasure was acquired by the museum in 1966 from a private collector who bought them from George Zakos, a dealer with black market ties in the trade in antiquities. Turkey has been requesting the return of the objects since 1968 to reunite them with the remaining treasure displayed in a museum in Antalya, Turkey. Dumbarton Oaks is of the opinion that there is no reasonable documentation of provenance compelling it to part with the treasure.

\section{Iraqi-Jewish artifacts:-}

Following the US Invasion of Iraq in 2003, the scholar Harold Rhode, an American specialist on the Middle East, found thousands of neglected, moldymanuscripts and documentsrelated to Iraq's ancient and mostly dispersed 
Jewish population in the war-damaged and flooded basement of Saddam Hussein's service headquarters in Baghdad.The artefacts include a Torah scroll fragment that includes parts of the Book of Genesis, a 400-year-old Hebrew Bible, a Zohar from 1815, a Babylonian Talmud from 1793, a lunar calendar in Hebrew and Arabic from 1972-3 and other books, personal papers, and sacred texts. Likening the repatriation to "giving the personal effects of Jews killed in the Holocaust back to Germany," Harold Rhodeis now pitching to prevent his discovery from being returned to an unstable Iraqi government and to a land still riddled with extremist views, internal strife and terrorist strikes.Currently on display at the National Archives in Washington, Rhode and his supporters contend that the findings belong to Iraqi Jews and not the Iraqi government.

\section{Chinese Imperial Treasures:-}

The Eight-Nation Alliance that put down the Boxer Rebellion in the late 19th century, ransacked the Forbidden City, looting its treasures before destroying the Old Summer Palace, known in Chinese as Yuanming Yuan or "Gardens of Perfect Brightness", originally called the Imperial Gardens.During the Second Opium War in 1880,on hearing that the truce delegation of over 20 officials sent by him were imprisoned and tortured to death the British High Commissioner to China, Lord Elgin, retaliated by ordering the complete destruction of the palace, which was undertaken by British and French troops, leaving a few buildings standing. Later, the palace was again sacked and completely destroyed in 1900 when the forces of the Eight-Nation Alliance invaded Beijing. Some of the most notable treasures ended up at the Chinese Museum in the Palace of Fontainebleau, which Empress Eugénie specifically set up in 1867 to house these newly acquired collections.Many relics which were taken from the Old Summer Palace still remain in foreign museums and private collections. The Chinese government has tried to recover them but only a few statuettes from the Garden of Eternal Spring have actually been returned.British Prime Minister David Cameron recently faced demands from Chinese state-run media and internet users to return of 23,000 priceless artifacts looted from Beijing in the 19th century that now lie in the British Museum.Britain, however, has continued to reject requests to return artifacts from other countries. 